\title{
Business Environment Changes and its Influence on Managerial Accountants' and Controllers' Professional Competence: Empirical Study ${ }^{\#}$
}

\author{
Bohumil KRÁL $L^{*}-$ Libuše ŠOLJAKOVÁ**
}

\section{Preface}

Especially features which are characteristic for the changes in business environment and growing managerial needs for a quality company management but also global crisis leading to recognition how important for the companies' success is the quality of their financial management manifest itself besides others in the growing pressure to competence of professional accountants and - in their frame - also controllers and managerial accountants as experts whose principle aim is to enhance primarily long-term financial effects on the basis of "accounting understanding of the world" and through the general coordination and optimisation of company processes.

This pressure is apparent in many sizes; it is demonstrated especially by

- newly formulated requirements of companies which are generalized in textbooks and the other outcomes from academia in which the ability and necessity of qualitative changes in the work of these experts has been stressed;

- reactions of universities and professional bodies with economic orientation which feels the necessity to implement these requirements into the education curricula and into the pre-qualification certification systems of professional competence development.

\# The article has been developed as one of the outcomes of the IGA project no. F1/4/2012 The impact of business environment changes on professional competence of company controllers and in the frame of institutional support of science no. IP100040.

Prof. Ing. Bohumil Král, CSc. - professor; Head of Department of Management Accounting, Faculty of Finance and Accounting, University of Economics, Prague, W. Churchill Sq. 4, 13067 Prague 3, Czech Republic; 〈kral@ vse.cz>.

** Doc. Ing. Libuše Šoljaková, Ph.D. - associated professor; Department of Management Accounting, Faculty of Finance and Accounting, University of Economics, Prague, W. Churchill Sq. 4, 13067 Prague 3, Czech Republic; <soljak@vse.cz>. 
Regarding the first stream of stakeholders enforcing these changes, for example Kaplan (1998) states that especially ICT development has enabled to liberate these experts from routine data processing, what gives them the opportunity to

- $\quad$ spend less time by the standardized statements development and conversely - to devote more attention to analyses and interpretation of submitted information;

- communicate more intensively companies' aims and means of their fulfillment with those people from departments who participate in the aims' realization; and

- shift the part of its work form the area of comparison of actual and desired companies' results to the area of decision-making about a future course of business process.

Similarly, according to Grandlund - Lukka (1998), controllers should not act as internal information support providers only, but more as business partners who are co-equal members of decision-making teams and as experts whose authority and responsibility is to explain why a certain type of information is or is not relevant for a certain decision and - consequently - who are expected to enhance the decision-making quality.

All above-stated changes in the content of controllers'/managerial accountants' work have been manifesting itself also in new requirements to professional competence and capabilities of these experts. Before, they were required to have adequate knowledge, skills and experience of the management accounting instruments and methods and their implementation and use in the frame of company information systems. Recently, they should use these knowledge, skills and experience more as means to successive aims - to ability to integrate on interdisciplinary basis management accounting information with the other non-financial and qualitative one, to capability to justify, interpret and present ascertained results, to give adequate information support for decisionmaking and to ability to strengthen companies' synergic effects through the communication and integration relations they develop and cultivate (see for example Burns - Yazdifar, 2001; Yasin, 2005).

Regarding the second group of stakeholders - universities and professional bodies which are implementers and supporters of these changes, the aim of this article is to describe the project whose general orientation is to define quality standards for the work of these experts and consequently to develop a framework for more precise specification of 
requirements for their education, skills and experience but also for their professional approaches, values and attitudes.

The "Czech version" of the project has been solving since the beginning of 2012. It has been used outcomes of IGC team ${ }^{1}$ and now it has been extending them in two principle lines: on the basis of

- Development of the project general grounds which comes from literature sources and from the requirements of professional bodies; and

- Empirically oriented research whose aim is to map principle requirements to professional competence of controllers/managerial accountants from two view angles:

- from the view-point of experts who are responsible for their professional competence development in the pre-qualification stage - during their stay at universities and in the frame of professional education and certification programs;

- from the view-point of managers and controllers/managerial accountants operating in business environment as experts who perceive the needs of their way of professional competence development "in the touch with business reality".

\section{Project general grounds}

General aim of the project is more complicated than it could appear prima facie. Requirements for competence of broader defined profession of so called professional accountants are harmonised relatively unambiguously on the base of the International Federation of Accountants (IFAC) International Education Standards (IFAC, 2003) and in the area of education they are even specified by United Nations Conference of Trade and Development (UNCTAD) Model Accounting Curriculum (UNCTAD, 2011); however, they are instruments of harmonisation which are oriented primarily to auditors as professional accountants acting in public interest. With regard to their specific role in the frame of accounting profession it

1 The project was initiated in the middle of 2011 by International Group of Controlling (IGC) - an international professional association in whose activities participate - by means of Czech Association of Financial Management - also members of the Management Accounting Department of the Faculty of Finance and Accounting of the University of Economics, Prague. However, due to shortage of sources to run it from the IGC level and to the changes of IGC priorities it was stopped very early as an international project and it was recommended to national bodies to realise it on national bases. 
is apparent that also requirements for their professional competence development will be different from experts whose principle orientation is to optimise companies" activities "from the inside".

Moreover: unlike auditors whose activities in the public interest have been the subject of legislative treatment (and afterwards also of worldwide harmonisation of juridical standards), analogous legal harmonisation of requirements for managerial competencies has been perceived to be not only useless but even harmful with regard to creation of barriers for the experts' free movement and monopolies' development for judgment of their quality.

Also historical development difference in the areas of managerial control and applied managerial approaches manifests itself by the fact that these experts are titled differently in various parts of the globe but they are also equipped by different level of authority and responsibility and they operate in different levels of a company hierarchy.

From this view-point there is no surprise that works on the project could not commence by an immediate discussion about quality standards; project team has decided to develop an initial general paper defined project conceptual grounds, its aim, content, structure and consensual terminology. So called "Draft for a common statement" which represented first stage of the project solution has become the subject of discussions by national IGC members.

This stage of investigation that has created framework for the consequent empirical research based on questionnaire has been the subject of paper which was published in European Financial and Accounting Journal at the end of 2011 (Král - Šoljaková, 2011). This is the reason why it is not the subject of description in this article.

\section{Empirical Research}

The aim of the empirical phase of research which follows the definition of conceptual general outcomes is to map how the revealed tendencies manifest themselves in the recent requirements to professional competence of controllers and management accountants; moreover, the question has been analyzing - as it has been already stated - from two view angles:

- from the view-point of experts who are responsible for their professional competence development in the pre-qualification stage; 
- from the view-point of managers and controllers/managerial accountants operating in business environment.

The research should give a comprehensive answer to question to what extend the changing requirements to professional competence of these experts are perceived by a practise and reflected by institutions which are responsible for their universal education.

With regard to this aim the questionnaire has been developed in two versions:

- version shortly titled "Controller/management accountant should be ...", designated for the first group of experts; and

- version shortly titled "Controller/management accountant is ...", designated for the second group.

Respondents of second group are random selected companies operating in the Czech Republic (number of employees over 100; turnover over 50 mil. EUR and sales also over 50 mil. EUR). Companies from various industries are included in the sample.

Concerning the content and structure of both versions they are identical to significant extend. Their basis has been derived from the above stated analysis of Draft for a common statement. However, also other materials have been used as inspiration sources, especially:

- IFAC International Standards for Professional Accountants (IFAC, 2003);

- Revised Model Accounting Curriculum (UNCTAD, 2011);

- syllabuses of specializations "Accounting and Company Financial Management" (Major) and "Controllership" (Minor) taught at the Faculty of Finance and Accounting of the University of Economics, Prague; and

- education and certification programs of professional competence development of both professional bodies operating in the Czech Republic - Chamber of Auditors and Union of Accountants.

Relatively broadly focused questionnaire, based especially on questions required scale of answers from 1 (strong disagreement) to 5 (strong agreement), but - in a lower extend - also requiring answers Yes or No and open answers, investigates the experts' opinions in the following problem areas:

- position of controllers / management accountants in the companies' organizational charts; 
- structure of departments of controllership / management accounting;

- relation of these departments to accounting, tax and other departments which - from different view-points are interested in company financial management;

- general content of the controllers'/ management accountants' activities;

- areas and extend of the controllers' authority and responsibility;

- specific content of the controllers'/ management accountants' activities;

- requirements for education;

- requirements for professional skills and practical experience;

- controllers' / management accountants role in ethical aspects of undertaking fulfillment;

- selection of potential candidates for a controller / management accountant positions; and

- quality assurance of the controllers'/ management accountants' work.

The intention of research team was to work with questionnaire in two stages:

- the aim of the firsts stage is to verify questionnaire's understand ability and completeness in individual interviews with $20-30$ representatives of both group of respondents; and

- on the base of this phase analysis to prepare both questionnaires into the shape which will be appropriate for their electronic distribution and assessment.

\section{Research results}

The research is in the stage in which:

- 27 interviews with experts of the first group have been realised and evaluated; 21 of them participated in the first stage (they also judged understand ability and completeness of questionnaire) and responded the questions of "Controller / management accountant should be ..." questionnaire; and

- 74 interviews with experts of the second group have been realised and evaluated; 5 of them participated in the first stage (they also judged understand ability and completeness of questionnaire) and responded the questions of "Controller / management accountant is be ..." questionnaire. 
The evaluation of the questionnaires has brought the following results.

\section{Controllers' position in the companies' organizational charts}

Present research has not bought unambiguous response regarding questions of controllers' position in the companies' organizational chart, desired structure of the departments assuring controllers' functions either their relations to accounting, tax and other departments engaged in various aspects of companies' financial management.

In our opinion, not only difficult generalization of progressive tendencies but also different Anglophone and Germanic approaches to these questions which are applied in the Czech business environment can be the main reasons of this ambiguity.

\section{General content of the controllers' activities}

Conversely, both groups of respondents (interviewed experts and managers/controllers) agreed relatively unambiguously on desired content of the controllers'/ management accountants' work. Especially correctness of data which are processed subsequently into the output information used in the managerial control and successive quality, availability and transparency of the information rendered to company management belong into the un-contradictory responsibility of these experts.

Both group of respondents also agreed a controller / management accountant should not bear primary responsibility for company financial results; nevertheless, we can notice slightly higher level of average and mode of responses provided by the second group of respondents (managers and controllers). In our opinion, it is possible to interpret this result in the sense that while the first group strictly refuses this responsibility, in practice controllers have some lower responsibility and they are motivated for financial results.

The outcomes of investigation are stated in Tab. 1. 
Tab. 1: General content of the controllers' activities

\begin{tabular}{|l|r|r|r|r|}
\cline { 2 - 5 } \multicolumn{1}{c|}{} & \multicolumn{2}{c|}{ "Should be" } & \multicolumn{2}{c|}{ "Is" } \\
\cline { 2 - 5 } \multicolumn{1}{c|}{} & Average & \multicolumn{1}{c|}{ Mode } & Average & Mode \\
\hline $\begin{array}{l}\text { Correctness of data processed } \\
\text { subsequently into the output } \\
\text { information used in the } \\
\text { managerial control }\end{array}$ & 3.92 & 5 & 4.46 & 5 \\
\hline $\begin{array}{l}\text { Quality of information } \\
\text { rendered to company } \\
\text { management }\end{array}$ & 4.46 & 5 & 4.26 & 5 \\
\hline $\begin{array}{l}\text { Availability of information for } \\
\text { company management }\end{array}$ & 4.13 & 5 & 3.94 & 5 \\
\hline $\begin{array}{l}\text { Transparency of information } \\
\text { rendered to company } \\
\text { management }\end{array}$ & 4.54 & 5 & 4.12 & 4 \\
\hline Financial results & 2.0 & 1 & 2.69 & 2 \\
\hline
\end{tabular}

Source: authors' calculations.

\section{Areas of the controllers' authority and responsibility}

In relation to general content, the questionnaire investigates desired and actual areas of the controllers' authority and responsibility. The results are stated in the following Tab. 2. They show the respondents' agreement in opinion that a controller should be equipped with adequate level of authority and responsibility in the areas in which he/she serves as

- Coordinator of activities connected with the company aims and means of their fulfillment formulation;

- Expert preparing scenarios of future solutions for management;

- Methodist who is responsible for company directives on pricing, costing, budgeting and management accounting development and who also pays attention to their adherence;

- Expert facilitating and supporting communication between departments in all areas of company management which requires coordination;

- Communicator who is responsible for reached results transfer to relevant management levels and who should comment, explain and interpret these results to managers; and - finally 
- Expert who should participate substantially in the regulations of a company financial management development including the system of remuneration and motivation.

We can remark significantly different results in the areas of coordination of activities connected with the company aims and means of their fulfillment formulation. According to the first group it is very important but according to the opinion of experts from companies, controllers do not support this area very intensively. That means in practice, controllers are more oriented on technical and process activities of controllership and information support of management and they are not involved so much in continual questions of the strategy formulation and implementation.

Relatively lower agreement exists between interviewed experts in opinion whether a controller should act as an originator of information system or its parts.

On the other hand, interviewed experts agreed a controller should not have an authority to influence source allocation (that means, for example he/she should not decide about the sold products volume and structure, accept make-or-buy decisions or about development / decline of customer, territory or distribution channels).

Tab. 2: Areas of authority and responsibility

\begin{tabular}{|l|r|r|r|r|}
\cline { 2 - 5 } \multicolumn{1}{c|}{} & \multicolumn{2}{c|}{ "Should be" } & \multicolumn{2}{c|}{ "Is" } \\
\cline { 2 - 5 } \multicolumn{1}{c|}{} & Average & Mode & Average & Mode \\
\hline $\begin{array}{l}\text { Coordination of activities } \\
\text { connected with the company } \\
\text { aims and means of their } \\
\text { fulfillment formulation }\end{array}$ & 4.29 & 5 & 3.03 & 3 \\
\hline $\begin{array}{l}\text { Preparation of scenarios of } \\
\text { future solutions }\end{array}$ & 4.21 & 5 & 3.28 & 3 \\
\hline $\begin{array}{l}\text { Information system or its parts } \\
\text { development }\end{array}$ & 3.67 & 4 & 3.13 & 3 \\
\hline $\begin{array}{l}\text { Development of company } \\
\text { directives on pricing, costing, } \\
\text { budgeting and management } \\
\text { accounting development and } \\
\text { examination of their adherence }\end{array}$ & 3.91 & 5 & 3.74 & 4 \\
\hline
\end{tabular}




\begin{tabular}{|l|r|r|r|r|}
\cline { 2 - 5 } \multicolumn{1}{c|}{} & \multicolumn{2}{c|}{ "Should be" } & \multicolumn{2}{c|}{ "Is" } \\
\cline { 2 - 5 } \multicolumn{1}{c|}{} & Average & \multicolumn{1}{c|}{ Mode } & Average & Mode \\
\hline $\begin{array}{l}\text { Reached results communication } \\
\text { to relevant management levels }\end{array}$ & 4.33 & 5 & 4.21 & 5 \\
\hline $\begin{array}{l}\text { Explanation and interpretation } \\
\text { of rendered information to } \\
\text { managers }\end{array}$ & 4.54 & 5 & 4.37 & 5 \\
\hline $\begin{array}{l}\text { Facilitation and support of } \\
\text { communication between } \\
\text { departments }\end{array}$ & 3.54 & 5 & 3.24 & 3 \\
\hline $\begin{array}{l}\text { Decision on resource allocation } \\
\text { Participation in the regulations } \\
\text { of a company financial } \\
\text { management development } \\
\text { including the system of } \\
\text { remuneration and motivation }\end{array}$ & 1.79 & 1 & 2.19 & 1 \\
\hline
\end{tabular}

Source: authors' calculations.

\section{Specific content of the controllers' activities}

Regarding specific content of the controllers' activities, the research has acknowledged their quite crucial role in ensuring the aims of target information - it means in planning and budgeting on the strategic, tactic and operational levels, including processing and presentation of forecasts, estimates and expectations. The respondents' answers also have stressed the importance of "traditional controllers' task" - adequate information support in the assuring of business factors and phases (research and development, purchasing, production, logistics, sale, human resources management etc.). Surprisingly, substantially lower agreement exists regarding controllers' participation in the management accounting system and connected internal reporting system development. Respondents also have not found strong agreement in response to question, to what extend controllers should bear responsibility for the quality of company project management, risk identification and management and organization structures development.

We can also notice the fundamental different answer in the area of information support in the controlling assuring of business factors and phases management (research and development, purchasing, production, logistics, sale, human resources management etc.) between experts and 
Král, B. - Šoljaková, L.: Business Environment Changes and its Influence on Managerial Accountants' and Controllers' Professional Competence: Empirical Study.

managers/controllers. Nevertheless, the difference in this opinion may be caused by sample of respondents; the companies included into pilot part of research have relatively closed business cycle and these factors are not applicable for them.

The results of this part investigation are stated in the following Tab. 3 .

Tab. 3: Specific content of the controllers'́ activities

\begin{tabular}{|l|r|r|r|r|}
\cline { 2 - 5 } \multicolumn{1}{c|}{} & \multicolumn{2}{c|}{ "Should be" } & \multicolumn{2}{c|}{ "Is" } \\
\cline { 2 - 5 } \multicolumn{1}{c|}{} & Average & Mode & Average & Mode \\
\hline $\begin{array}{l}\text { Strategic planning and } \\
\text { budgeting }\end{array}$ & 4.29 & 5 & 4.13 & 5 \\
\hline Tactical planning and budgeting & 4.21 & 5 & 4.12 & 5 \\
\hline $\begin{array}{l}\text { Operational planning and } \\
\text { budgeting }\end{array}$ & 4.04 & 4 & 4.07 & 5 \\
\hline $\begin{array}{l}\text { Expectations and forecasts } \\
\text { development }\end{array}$ & 4.29 & 5 & 4.46 & 5 \\
\hline $\begin{array}{l}\text { Reached results communication } \\
\text { to relevant management levels }\end{array}$ & 4.33 & 5 & 4.12 & 5 \\
\hline $\begin{array}{l}\text { Participation in the management } \\
\text { accounting and internal } \\
\text { reporting systems development }\end{array}$ & 4.00 & 4 & 4.12 & 5 \\
\hline $\begin{array}{l}\text { Participation in the project } \\
\text { management system } \\
\text { development }\end{array}$ & 3.54 & 3 & 2.57 & 3 \\
\hline $\begin{array}{l}\text { Participation in the risk } \\
\text { identification and management } \\
\text { system development }\end{array}$ & 3.33 & 3 & 2.79 & 4 \\
\hline $\begin{array}{l}\text { Information support in the } \\
\text { controlling assuring of business } \\
\text { factors and phases management } \\
\text { (research and development, } \\
\text { purchasing, production, sale, } \\
\text { logistics, human resources etc.) }\end{array}$ & 4.17 & 5 & 3.44 & 2 \\
\hline $\begin{array}{l}\text { Organization structures } \\
\text { development and enhancement } \\
\text { including connecting activities }\end{array}$ & 2.88 & 3 & 2.33 & 1 \\
\hline
\end{tabular}

Source: authors' calculations. 


\section{Requirements for education}

Research focuses also on requirement for education of controllers. Regarding structure of these requirement the questionnaire has come from the structure of knowledge defined by the IFAC International Education Standards as well as UNCTAD Revised Model Accounting Curriculum and it has taken into consideration also the structure and content of initial (pre-qualification) programs of Chamber of Auditors and Union of Accountants.

Both groups of respondents strongly highlight the financial accounting and reporting, management accounting and corporate finance knowledge requirement. What is surprising, the group "is" even prefers knowledge of financial accounting over management accounting one. According both groups of respondents, other areas of controllers' knowledge relevant for their work are taxation, internal control system, business administration and information and communication technology. On the other hand, knowledge of law, auditing, marketing and international aspects of business have low importance according both groups of respondents.

The detail outcomes of investigation are shown in Tab. 4.

Tab. 4: Requirements for education

\begin{tabular}{|l|r|r|r|r|}
\hline $\begin{array}{l}\text { Controller has been has been } \\
\text { able to use knowledge } \\
\text { from the following areas: }\end{array}$ & \multicolumn{2}{|c|}{ "Should be" } & \multicolumn{2}{|c|}{ "Is" } \\
\cline { 2 - 5 } & Average & Mode & Average & Mode \\
\hline $\begin{array}{l}\text { Financial accounting and } \\
\text { reporting }\end{array}$ & 4.71 & 5 & 4.59 & 5 \\
\hline Management accounting & 4.92 & 5 & 4.49 & 5 \\
\hline Corporate finance & 4.63 & 5 & 4.20 & 5 \\
\hline Taxation & 3.79 & 4 & 3.06 & 3 \\
\hline Business law & 3.17 & 3 & 2.46 & 2 \\
\hline Labour Law & 2.83 & 3 & 2.25 & 2 \\
\hline Social and health insurance Law & 2.75 & 3 & 2.33 & 2 \\
\hline Auditing & 3.42 & 4 & 3.03 & 3 \\
\hline Internal control systems & 3.96 & 5 & 3.53 & 4 \\
\hline Economics & 3.25 & 3 & 3.74 & 4 \\
\hline Management & 3.75 & 3 & 3.26 & 4 \\
\hline
\end{tabular}


Král, B. - Šoljaková, L.: Business Environment Changes and its Influence on Managerial Accountants' and Controllers' Professional Competence: Empirical Study.

\begin{tabular}{|l|r|r|r|r|}
\hline $\begin{array}{l}\text { Controller has been has been } \\
\text { able to use knowledge } \\
\text { from the following areas: }\end{array}$ & \multicolumn{2}{|c|}{ "Should be" } & \multicolumn{2}{|c|}{ "Is" } \\
\cline { 2 - 5 } & Average & Mode & Average & Mode \\
\hline Business administration & 4.21 & 5 & 4.00 & 5 \\
\hline Marketing & 2.79 & 3 & 2.16 & 2 \\
\hline $\begin{array}{l}\text { Quantitative Methods } \\
\text { Mathematics, Statistics) }\end{array}$ & 3.58 & 4 & 3.21 & 3 \\
\hline $\begin{array}{l}\text { International aspects of } \\
\text { business }\end{array}$ & 2.88 & 3 & 2.73 & 3 \\
\hline $\begin{array}{l}\text { Information and communication } \\
\text { technology (ICT) }\end{array}$ & 3.75 & 3 & 3.27 & 3 \\
\hline
\end{tabular}

Source: authors' ${ }^{\prime}$ calculations.

Currently controlling and management accounting practice is very influenced by ICT; this tendency has been stressed in many above stated sources. This has been the reason why we have devoted one special part of our questionnaire to this issue.

Generally, responses of both groups have acknowledged the fact that development of ICT has been changing the substance of controllers' work and - also conversely - controllers are required to participate actively in the ICT system development.

Regarding more specific areas of investigation, the questionnaire has tried to ascertain the role of controllers in the area of ICT, especially whether they act as users of ICT only or whether they also participate actively in the ICT development. According to both groups, controllers are considered mainly ICT users, less originators and verifier of processing and user quality. Surprisingly for us, both groups also have agreed with statement that controllers should not serve as managers of ICT projects.

The results of this part of investigation are stated in the following Tab. 5 .

Tab. 5: ICT competencies

\begin{tabular}{|l|r|r|r|r|}
\hline \multirow{2}{*}{$\begin{array}{l}\text { In the area of ICT controller } \\
\text { acts especially as }\end{array}$} & \multicolumn{2}{|c|}{ "Should be" } & \multicolumn{2}{c|}{ "Is" } \\
\cline { 2 - 5 } & Average & \multicolumn{1}{|c|}{ Mode } & Average & \multicolumn{1}{c|}{ Mode } \\
\hline $\begin{array}{l}\text { User (with stress on areas } \\
\text { he/she uses) }\end{array}$ & 4.26 & 5 & 4.48 & 5 \\
\hline Creator (with stress on areas & 3.30 & 4 & 3.25 & 4 \\
\hline
\end{tabular}




\begin{tabular}{|l|r|r|r|r|}
\hline \multirow{2}{*}{$\begin{array}{l}\text { In the area of ICT controller } \\
\text { acts especially as }\end{array}$} & \multicolumn{2}{|c|}{ "Should be" } & \multicolumn{2}{|c|}{ "Is" } \\
\cline { 2 - 5 } & Average & \multicolumn{1}{c|}{ Mode } & Average & Mode \\
\hline he/she uses) & & & & \\
\hline $\begin{array}{l}\text { Originator or verifier of } \\
\text { processing quality }\end{array}$ & 3.70 & 3 & 3.13 & 3 \\
\hline $\begin{array}{l}\text { Originator or verifier of user } \\
\text { quality }\end{array}$ & 3.91 & 4 & 3.51 & 4 \\
\hline $\begin{array}{l}\text { Manager of ICT projects or } \\
\text { their parts }\end{array}$ & 2.71 & 2 & 2.91 & 3 \\
\hline
\end{tabular}

Source: authors' calculations.

\section{Requirements for professional skills and practical experience}

The research also focuses on relation between technical skills (analysed in Tab. 4) and soft skills (professional skills and practical experience). Also their structure is derived from the overview that is mentioned especially in IFAC International Education Standard 3 Professional skills but also from the other sources, mentioned in section devoted to education requirements.

Table 6 shows results of this investigation. Both groups of respondents consider the stated soft skills to be important for controllers' activities; nevertheless, technical skills reach slightly higher values. What is interesting, respondents of the first group consider soft skills to be more relevant in comparison with managers / controllers responses. In our opinion, one of the reasons can be the fact that recently soft skills of controllers do not reach required level yet in the Czech Republic, but "practice" is not convinced about their importance up to now.

Tab. 6: Requirements for professional skills and practical experience

\begin{tabular}{|l|r|r|r|r|}
\hline \multirow{2}{*}{$\begin{array}{l}\text { It is important for a controller } \\
\text { to develop especially }\end{array}$} & \multicolumn{2}{|c|}{ "Should be" } & \multicolumn{2}{|c|}{ "Is" } \\
\cline { 2 - 5 } & Average & \multicolumn{1}{|c|}{ Mode } & Average & \multicolumn{1}{c|}{ Mode } \\
\hline Communication skills & 4.38 & 5 & 4.10 & 4 \\
\hline $\begin{array}{l}\text { Abilities to act with people and } \\
\text { enforce his/her opinions }\end{array}$ & 4.46 & 5 & 4.06 & 4 \\
\hline Presentation skills & 4.58 & 5 & 4.22 & 4 \\
\hline $\begin{array}{l}\text { Managerial and organizational } \\
\text { skills }\end{array}$ & 3.63 & 3 & 3.79 & 3 \\
\hline
\end{tabular}


Král, B. - Šoljaková, L.: Business Environment Changes and its Influence on Managerial Accountants' and Controllers' Professional Competence: Empirical Study.

\begin{tabular}{|l|r|r|r|r|}
\hline \multirow{2}{*}{$\begin{array}{l}\text { It is important for a controller } \\
\text { to develop especially }\end{array}$} & \multicolumn{2}{|c|}{ "Should be" } & \multicolumn{2}{|c|}{ "Is" } \\
\cline { 2 - 5 } & Average & Mode & Average & Mode \\
\hline $\begin{array}{l}\text { Language knowledge including } \\
\text { ability to use them }\end{array}$ & 3.57 & 3 & 3.63 & 4 \\
\hline
\end{tabular}

Source: authors' calculations.

\section{Controllers' role in ethical aspects of undertaking fulfilment}

According to the results of research, both groups of respondents generally agree with the hypothesis that it is important for a company to define, enhance, support and communicate effectively ethical principles and rules of undertaking.

However, on the other hand, research confirms quite poor level of application of ethical principles and rules in business. This fact is quite apparent from the comparison of responses of both groups to the third answer, stated in the following Tab. 7: according to the first group of experts, it is very important to incorporate these standards into company standards, codes and guidelines. However, this importance is not followed by the "state of the art" declared by second group of respondents.

What is very un-satisfactory is the role of controllers is the process of ethical aspects of undertaking enforcement. While first group of respondents (and also all generally accepted standards and guidelines interested in ethical aspects of professional accountants' activities) evaluate this size of controllers' work like quite important, according to the second group of respondents recent stage in companies shows great reserves and inspirations for the future.

The results of this part of investigation are stated in the following Tab. 7.

Tab. 7: Controllers' role in ethical aspects of undertaking fulfillment

\begin{tabular}{|l|r|r|r|r|}
\cline { 2 - 5 } \multicolumn{1}{c|}{} & \multicolumn{2}{c|}{ "Should be" } & \multicolumn{2}{c|}{ "Is" } \\
\cline { 2 - 5 } \multicolumn{1}{c|}{} & Average & \multicolumn{1}{c|}{ Mode } & Average & Mode \\
\hline $\begin{array}{l}\text { It is important for a company to } \\
\text { define, enhance, support and } \\
\text { communicate effectively ethical } \\
\text { principles and rules of business }\end{array}$ & 4.58 & 5 & 4.13 & 5 \\
\hline $\begin{array}{l}\text { These principles and rules are } \\
\text { explicitly incorporated into }\end{array}$ & 4.50 & 5 & 3.90 & 5 \\
\hline
\end{tabular}




\begin{tabular}{|l|r|r|r|r|}
\cline { 2 - 5 } \multicolumn{1}{c|}{} & \multicolumn{2}{c|}{ "Should be" } & \multicolumn{2}{c|}{ "Is" } \\
\cline { 2 - 5 } \multicolumn{1}{c|}{} & Average & Mode & Average & Mode \\
\hline $\begin{array}{l}\text { company standards, codes and } \\
\text { guidelines }\end{array}$ & & & & \\
\hline $\begin{array}{l}\text { Controller participates in the } \\
\text { ethical company standards, } \\
\text { codes and guidelines } \\
\text { development }\end{array}$ & 3.63 & 4 & 2.49 & 3 \\
\hline $\begin{array}{l}\text { In the scope of his/her } \\
\text { authorities and responsibilities } \\
\text { controller participates in the } \\
\text { inspection of these standards, } \\
\text { codes and guidelines fulfillment }\end{array}$ & 3.38 & 3 & 3.16 & \\
\hline $\begin{array}{l}\text { Controller serves as informal } \\
\text { authority in these standards, } \\
\text { codes and guidelines fulfillment } \\
\text { - in internal company } \\
\text { environment as well as } \\
\text { externally }\end{array}$ & 3.38 & & & \\
\hline
\end{tabular}

Source: authors' calculations.

\section{Human resources management}

Section devoted to human resources management is concentrated to two basic problem areas:

- to selection of potential candidates for a controller position; and

- to attention which is devoted to controllers' continuing professional development.

Interesting outcomes provides especially the questions relating to selection of potential candidates for a controller position.

First: the education and practical experience are considered to be more important than personal features and communications skills for both groups of respondents; nevertheless, the difference is small and confirms high importance of communication and presentation skills.

Second: relatively high importance is also given to language knowledge; partly mode by the group of managers of controllers is 5 . The reason is probably given by the fact a lot of companies in the sample belong to multinational corporations and effective communication with 
Král, B. - Šoljaková, L.: Business Environment Changes and its Influence on Managerial Accountants' and Controllers' Professional Competence: Empirical Study.

higher corporate levels and other network members has a great importance.

The concrete results of investigation are shown in Tab. 8 .

Tab. 8: Selection of potential candidates for a controller position

\begin{tabular}{|l|r|r|r|r|}
\hline $\begin{array}{l}\text { In the process of potential } \\
\text { controller selection it is } \\
\text { important to take into } \\
\text { consideration }\end{array}$ & \multicolumn{2}{|c|}{ "Should be" } & \multicolumn{2}{|c|}{ "Is" } \\
\cline { 2 - 5 } & Average & Mode & Average & Mode \\
\hline Previous education & 4.17 & 5 & 4.03 & 4 \\
\hline Present practical experience & 4.38 & 5 & 4.50 & 5 \\
\hline $\begin{array}{l}\text { Ability to act with people and } \\
\text { personality profile }\end{array}$ & 4.08 & 4 & 4.06 & 4 \\
\hline $\begin{array}{l}\text { Communication abilities and } \\
\text { skills }\end{array}$ & 4.33 & 5 & 4.04 & 4 \\
\hline ICT competencies & 3.67 & 3 & 3.75 & 4 \\
\hline Language knowledge & 3.57 & 3 & 3.44 & 4 \\
\hline
\end{tabular}

Source: authors' ${ }^{\prime}$ calculations.

Analysis of area devoted to controllers' continuing professional development confirms that both groups of respondents consider the professional development quite crucial for the quality of controllers' work. Management enables quite currently continuing professional development to its controllers - especially in the cases the company controllers are active in searching the opportunities for it; but according to the second group of respondents, company management does not devote adequate attention to the fact whether controllers enhance their professional competence - especially if they are passive in this regard.

Important is the result that most of controlling departments consists of stable team of experts which do not fluctuate very much and controllers remuneration is on average - above average level.

The results of this part of investigation are stated in the following Tab. 9. 
Tab. 9: Controllers' professional development

\begin{tabular}{|l|r|r|r|r|}
\cline { 2 - 5 } \multicolumn{1}{l|}{} & \multicolumn{2}{c|}{ "Should be" } & \multicolumn{2}{c|}{ "Is" } \\
\cline { 2 - 5 } \multicolumn{1}{l|}{} & Average & Mode & Average & Mode \\
\hline $\begin{array}{l}\text { Department of controlling } \\
\text { consists of stable team of } \\
\text { experts which do not fluctuate } \\
\text { very much }\end{array}$ & 3.75 & 3 & 4.11 & 4 \\
\hline $\begin{array}{l}\text { In comparison with employees } \\
\text { operating on the same } \\
\text { organizational level, controllers } \\
\text { are above-the-average paid }\end{array}$ & 3.30 & 3 & 3.57 & 4 \\
\hline $\begin{array}{l}\text { Continuing professional } \\
\text { development is quite crucial for } \\
\text { the quality controllers' work }\end{array}$ & 4.58 & 5 & 4.43 & 5 \\
\hline $\begin{array}{l}\text { Company management enables } \\
\text { to its controllers continuing } \\
\text { professional development }\end{array}$ & 4.63 & 5 & 3.75 & 4 \\
\hline $\begin{array}{l}\text { Company management verifies } \\
\text { whether controllers enhance } \\
\text { their professional competence }\end{array}$ & 4.17 & 5 & 2.76 & 3 \\
\hline
\end{tabular}

Source: authors' calculations

\section{Quality assurance of the controllers' work}

Data gained from the part of questionnaire devoted to the quality assurance confirm necessity of regular evaluation of controllers' work. On the other hand, answers to open question "How is the controllers' work evaluated?" has been responded very generally - for example through the annual or regular interviews or - in multinational corporations - by un-concrete explanation "the evaluation is realised on holding level".

The results of this part of investigation are stated in the following Tab. 10. 
Král, B. - Šoljaková, L.: Business Environment Changes and its Influence on Managerial Accountants' and Controllers'Professional Competence: Empirical Study.

Tab. 10: Quality assurance of the controllers' work

\begin{tabular}{|c|c|c|c|c|}
\hline & \multicolumn{2}{|c|}{ "Should be" } & \multicolumn{2}{|c|}{ "Is" } \\
\hline & Average & Mode & Average & Mode \\
\hline $\begin{array}{l}\text { Controllers' work quality is } \\
\text { regularly checked and } \\
\text { evaluated }\end{array}$ & 4.48 & 5 & 3.85 & 5 \\
\hline $\begin{array}{l}\text { Controllers' work quality } \\
\text { assurance includes }\end{array}$ & & & & \\
\hline - Entering data correctness & 4 & 5 & 4.04 & 4 \\
\hline - Information relevance & 4.67 & 5 & 3.87 & 4 \\
\hline $\begin{array}{l}\text { - Timelines of rendered } \\
\text { information }\end{array}$ & 4.52 & 5 & 3.54 & 4 \\
\hline $\begin{array}{l}\text { - Formal level of rendered } \\
\text { information }\end{array}$ & 4.17 & 4 & 3.69 & 4 \\
\hline $\begin{array}{l}\text { - Neutrality and objectivity } \\
\text { of information }\end{array}$ & 4.71 & 5 & 3.71 & 4 \\
\hline - Information flexibility & 4.09 & 5 & 4.15 & 5 \\
\hline $\begin{array}{l}\text { - Information comparability } \\
\text { and consistency }\end{array}$ & 4.67 & 5 & 4.04 & 4 \\
\hline
\end{tabular}

Source: authors' calculations.

\section{Conclusions}

Although the project solution has investigated the situation in the Czech Republic only, concrete suggestions regarding individual above stated problem areas should be derived from the results of empirical research and bring some important inspirations for the controllers' professional development management:

- Controllers are required to be responsible primarily for availability and transparency of the information rendered to company management; on the other hand they should not be responsible primarily for company the financial results;

- In the area of requirements for education, both groups of respondents strongly highlight the financial accounting and reporting, management accounting and corporate finance knowledge; on the other hand, knowledge of law, auditing, marketing and international aspects of 
business are considered to have lower importance; In the ICT area, controller is considered to mainly user, less originator and verifier of processing and user quality;

- In the area of requirements for professional skills and practical experience, both groups of respondents consider the soft skills to be important; nevertheless, they perceive technical skills even more relevant for the controllers' professional competence. According to the research, however, the recent situation in the Czech Republic in worse in the area of soft skills of controllers as company managers are not convinced about their importance;

- Both groups of respondents also confirm how important for a company is to define, enhance, support and communicate effectively ethical principles and rules of undertaking; on the other hand, research also confirms very poor level of application of ethical principles and rules of business in practice; this is the reason why this aspect should be incorporated into the quality standards as very important one;

- Results of the controllers' professional development needs investigation confirm that both group of respondents consider the professional development to be quite crucial for the quality of the controllers' work; in this regard, management enables to its controllers continuing professional development, but it does not verify always whether controllers enhance their professional competence;

- Statistical results of quality assurance of the controllers' work confirm necessity of evaluation of controllers work. On the other hand answer, open questions "How is the controllers' work evaluated?" has been responded very generally.

\section{References:}

[1] Burns, J. - Yazdifar, H. (2001): Trick or treats? Financial Management, 2001, vol. 30, no. 1, pp. 33-35.

[2] Grandlund, M. - Lukka, K. (1998): Towards increasing business orientation: Finish management accountants in a changing cultural context. Management Accounting Research, 1998, vol. 9, no. 2, pp.185-211.

[3] IFAC (2003): International Education Standards for Professional Accountants. New York, International Federation of Accountants, 2003. 
Král, B. - Šoljaková, L.: Business Environment Changes and its Influence on Managerial Accountants' and Controllers' Professional Competence: Empirical Study.

[4] Kaplan, R. - Cooper, R. (1998): Cost and Effect: Using Integrated Systems to Drive Profitability and Performance. Boston, Harvard Business School Press, 1998.

[5] Král, B. - Šoljaková, L. (2011): Harmonization of Requirements for Professional Competence of Managerial Accountant and Controllers. European Financial and Accounting Journal, 2011, vol. 6, no. 3, pp. 720.

[6] UNCTAD (2011): Revised Model Accounting Curriculum. Geneva, United nations Conference on Trade and Development, 2011.

[7] Yasin, M. M. - Bayes, P. E. - Czuchry, A. J. (2005): Changing role of accounting in supporting the quality and customers goals of organizations: an open system perspectives. International Journal of Management, 2005, vol. 22, no. 3, pp. 322-331. 


\title{
Business Environment Changes and its Influence on Managerial Accountants' and Controllers' Professional Competence: Empirical Study
}

Bohumil KRÁL - Libuše ŠOLJAKOVÁ

\begin{abstract}
The article describes the outcomes of the project whose purpose is - on the base of "Draft for a common statement" - to state generally accepted requirements for professional competence of managerial accountants and controllers.

The important part of the project is empirical research focused on changing requirements on managers and controllers and mapping actual situation in the Czech Republic in this area. The research compares opinions of two groups of respondents - experts who are responsible for professional competence development of controllers on one hand and managers and controllers operating in business environment on the other hand.

Paper provides results relating to following areas: general content of the controllers' activities, controllers' authority and responsibility, requirements for controllers' education, professional skills and practical experience, ethical aspects of management accounting as well as quality assurance of the controllers' work.
\end{abstract}

Key words: Professional competence; Controller; Management accountant; Developmental tendencies.

JEL classification: M41. 